\title{
Biometric responses of third ratoon sugarcane varieties under variable water regime
}

\author{
Francisco Rodolfo Junior ${ }^{*}$, Walter Quadros Ribeiro Junior², Maria Lucrécia Gerosa Ramos³, \\ Fábio Pedro da Silva Batista ${ }^{3}$, Cristiane Andréa de Lima², Omar Cruz Rocha²
}

\author{
'Federal University of Piauí, Bom Jesus, Pl, Brazil \\ ${ }^{2}$ Embrapa Cerrados, Planaltina, DF, Brazil \\ 3University of Brasília, Brasília, DF, Brazil \\ *Corresponding author, e-mail: rodolfo@ufpi.edu.br
}

\begin{abstract}
Water deficit is one of the main factors to limit sugar cane production. This paper's goal is to characterize biometrically varieties of sugarcane under different water regimes. The experiment was performed using randomized design with three repetitions in parcels subdivided in time, in which three varieties: RB855156, RB835486 e RB867515 (plots), with absence and presence of irrigation (irrigated and rainfed - subplots) to which the plants were subjected, and data collection in six observations in time $(50,100,150,200,250$ and 300 days after cutting - DAC), were the subsubplots. The following biometrics were assessed: mean stem diameter (MSD), mean tiller height (MTH), number of green and completely open leaves (NOFOGL), length and width of +3 leaf $(C+3$ and $L+3$, respectively), leaf area index (LAI), leaf area (LA) and productivity. The data were subjected to variance analysis and regression at $p<0.05$. The variety RB867515 was the one that displayed higher MSD, MTH, C+3 and L+3 biometric values, both in irrigated cultivation and rainfed; it was observed that there was a decrease in NoFOGL values per tiller when the varieties were grown in rainfed conditions; the RB867515 variety had higher productivity, not differentiating to the RB855156, and proved better suited to water stress during the beginning of cultivation cycle.
\end{abstract}

Keywords: Saccharum spp L., drought stress, vegetative growth, productivity

\section{Introduction}

Sugarcane (Saccharum spp. L.) has significant importance for the Brazilian economy. Its by products are used on a large scale and with the increase in the sugar and ethanol sector's demand, it reaches an estimated production of 39.46 million tons and the States of São Paulo, Mato Grosso do Sul, Goiás and Paraná registered expansion of the planted areas with this crop (Conab, 2014).

In tropical countries, such as Brazil, environmental factors as high temperatures and long periods of drought can cause hydric stress, reducing leaf area and, consequently, accelerating senescence of green leaves, in order to reduce the transpiration area at leaf surface, as occurs in cases of varieties that are considered sensitive to water restriction (InmanBamber \& Smith, 2005). The leaf area, vegetative growth dynamics and others vegetative growth indexes to sugarcane varieties are related with higher productive efficiency of the crop in tons of stem per hectare, and with accumulation of sugars in the stem (Oliveira et al., 2007).

The geographic areas that are appropriated to sugarcane expansion in Brazil are almost in its totality at Cerrado biome, being at Midwest region the largest area increment in the sector for the 2014/2015 harvest, with an increase of $7.32 \%$ (Conab, 2014). In this way, the 
choise of tolerant varieties to water deficiency in the new areas of sugarcane expansion makes planting safer and economically more viable (Peixoto et al., 2007; Ecco et al., 2014), mainly because in these areas a long hydric deficiency season is common (Sano et al., 2008). The esponse to water restriction may vary according to the sugarcane genotype including from cellular responses to morphological changes. However these characteristics are expressed in severals way and depends on the environmental conditions and crop management (Inman Bamber \& Smith, 2005). In addition, Shigaki et al. (2004) affirm that for regions with long water deficit periods, as occur in the Cerrado biome, the correct choice of adapted varieties to the different climatic and edaphic conditions is the limiting factor for a more efficient and gainful sugarcane production, so the producer must choose resistant varieties to water stress, pests and diseases.

Researches on the behavior of sugarcane varieties, applying biometric growth analyzes, are important tools to investigate the structural and functional differences of each variety, as well as the production potential of each one, allowing its use for genetic breeding studies, in order to make possible the use of varieties adapted to the climatic conditions of each country regions(Dantas Neto et a., 2006;
Carlin et al., 2008; Farias et al., 2009; Carvalho et al., 2009). Therefore, using the measurement of biometric data is possible to observe potential reductions in the behavior of sugarcane growth, which shows potential reduces in conditions of water deficiency of sugarcane cultivation, and it is possible to highlight the number of leaves, the leaf area (Smit \& Singel, 2006) the plant height and stem diameter (Silva et al., 2012a).

The goal of this work was to characterize biometrically the varieties of sugarcane, exposed to different hydric regimes.

\section{Material and Methods}

The experiment was conducted under field conditions between April 2013 and April 2014, in an area of 0.36 hectares, situated at Embrapa Cerrados (CPAC), located at BR 020, $\mathrm{Km} 18$ (latitude $15^{\circ} 39 ' 84^{\prime \prime}$ South and longitude $47^{\circ}$ $44^{\prime} 41^{\prime \prime}$ West), near to the Administrative Region of Planaltina-DF. The altitude of the area is around $1014 \mathrm{~m}$ with an annual rainfall and temperature average of $21.9^{\circ} \mathrm{C}$ and $1395.6 \mathrm{~mm}$, respectively. The weather of the region is classified as Aw, tropical with rainfed winter and rainy summer, according to Köppen. There may be drought periods during the rainy season (Sano et al., 2008).

The rainfall data, reference evapotranspiration (ETO), maximum, minimum and mean temperatures (oC) during the experimental

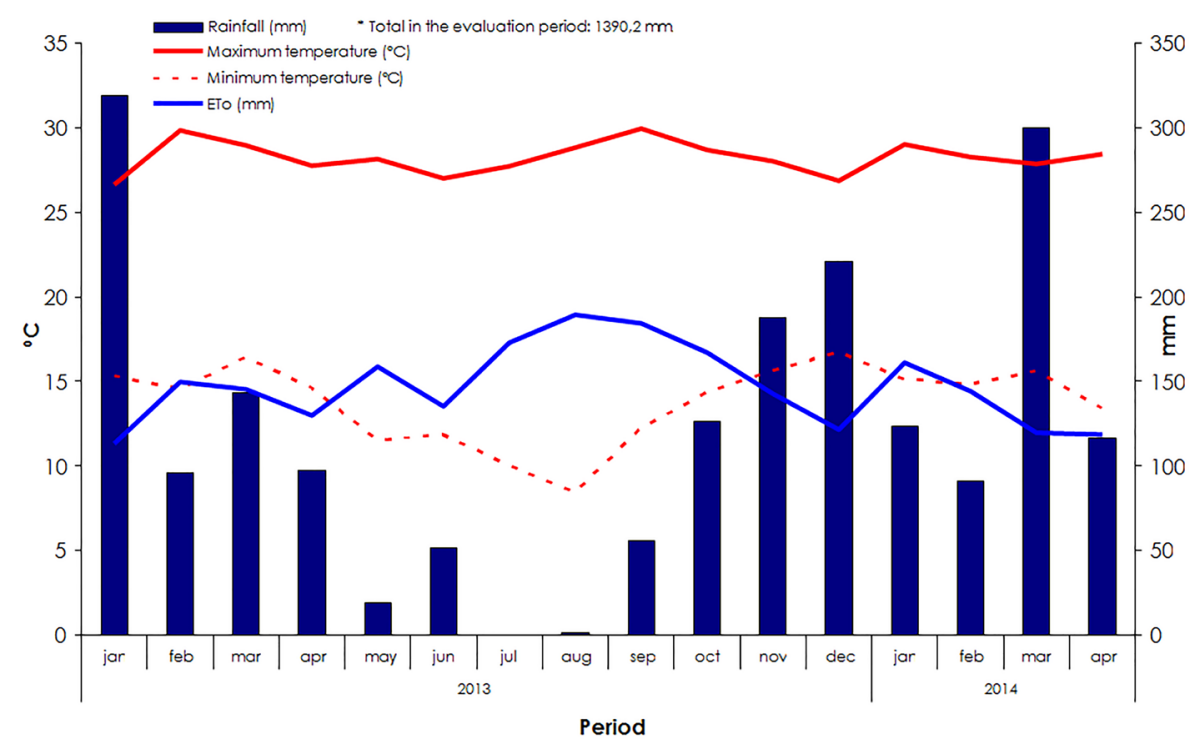

Figure 1. Rainfall, reference evapotranspiration (ETO), maximum temperature $\left({ }^{\circ} \mathrm{C}\right)$, minimum temperature $\left({ }^{\circ} \mathrm{C}\right)$ of the Administrative Region of Planaltina-DF during the period of 05/05/2013 to 04/04/2014. Data collected at Embrapa Cerrados Meteorological Station, Planaltina-DF (2013). 
conduction are presented in Figure 1.

The soil of the experimental area is classified as a RED LATOSOL Typical distrophic, clayey texture, moderate A. The granulometric analysis was obtained in the depth of 0 to $20 \mathrm{~cm}$ with $601,116,47$ and $236 \mathrm{~g} \mathrm{~kg}^{-1}$ of clay, silt, fine and coarse sands, respectively. The chemical characterization (Table 1) was performed before experiment installation, according to Embrapa methodology (1997).

Table 1. Chemical characterization of the soil from sugarcane cultivation area. Embrapa Cerrados, Planaltina-DF (2013).

\begin{tabular}{|c|c|c|c|c|c|c|c|c|}
\hline $\begin{array}{c}\text { Depth } \\
----\mathrm{cm}^{----} \\
\end{array}$ & $\mathrm{pH} \mathrm{H}_{2} \mathrm{O}$ & $\begin{array}{c}\mathrm{Al} \\
--\mathrm{cmol}_{\mathrm{c}} \mathrm{dm}^{-3}--\end{array}$ & $\begin{array}{c}P \\
----~ m \\
\end{array}$ & $\begin{array}{c}K \\
n^{-3}---- \\
\end{array}$ & $\mathrm{Ca}$ & $\begin{array}{l}\mathrm{Mg} \\
\mathrm{nol}_{\mathrm{c}} \mathrm{dr}\end{array}$ & $\mathrm{H}+\mathrm{Al}$ & $\begin{array}{l}\text { OM } \\
---\%---\end{array}$ \\
\hline $0-20$ & 5,08 & 0,39 & 0,22 & 8,00 & 0,56 & 0,26 & 3,70 & 0,87 \\
\hline $20-40$ & 5,20 & 0,04 & 0,50 & 16,00 & 1,19 & 0,68 & 3,46 & 1,15 \\
\hline $40-60$ & 5,16 & 0,13 & 0,76 & 32,00 & 0,96 & 0,52 & 3,30 & 1,30 \\
\hline $60-80$ & 5,13 & 0,19 & 0,83 & 22,00 & 1,08 & 0,44 & 3,18 & 1,30 \\
\hline $80-100$ & 5,10 & 0,24 & 0,81 & 30,00 & 0,99 & 0,53 & 3,60 & 1,30 \\
\hline
\end{tabular}

It was made a corrective adubation (at broadcast and incorporated) of agricultural gypsum $500 \mathrm{~kg} \mathrm{ha}^{-1}$, and $50 \mathrm{~kg} \mathrm{ha}^{-1}$ of FTE BR-10 (powder) as micronutrient source (Zn, B, Cu, Fe, Mn and Mo with 7.0, 2.5, 1.0, 4.0, 4.0 and $0.1 \%$ respectively) and the crop adubation, with a dose of $600 \mathrm{~kg} \mathrm{ha}^{-1}$ of NPK with the formulation 04 30-16. Planting of sugarcane was done manually on June 18, 2010, using three varieties, RB855156, RB835486 both of early maturation and RB867515 with late maturation as a reference variety because it is the most used in Brazil (Camargo \& Vitti, 2014).

The opdressing adubation was applied manually and after the first harvest of plants, it was carried out in two periods at the beginning of May with a dose of $400 \mathrm{~kg} \mathrm{ha}^{-1}$ of NPK (formulation 20-00-20) and in November 2011 with the dose of $600 \mathrm{~kg} \mathrm{ha}^{-1}$ of NPK (formulation 20-00-24), repeating this same fertilization on later years. In May 2011 the first harvest of the cane-plant was carried out and after the new sprouting of sugarcane was made the second harvest of ratoon cane in April of 2012; the third harvest was carried out in May 2013 and the fourth harvest in April 2014. Approximately 20 to 30 days after each harvest, a rescue irrigation with a water depth of approximately $60 \mathrm{~mm}$ was made due to the low precipitation in this period. The three sugarcane varieties (RB855156, RB835486 and RB867515) were submitted to two irrigation regimes: Irrigated (I) and Rainfed (R). The irrigation management standard was based on the climatic monitoring (water balance) with data collected from January 2013 to April 2014 at the meteorological station located at $100 \mathrm{~m}$ of the experiment, with the irrigation shift fixed in nine days. The crop evaporation was obtained from the reference evaporation estimated by the Penman-Monteith model (Fernandes et al., 2012) and the estimated crop coefficients as a function of the number of days after cutting, according to Silva et al. (2012b). In the experimental area, the irrigation was performed by a self-propelled irrigation system (Figure 2) and conjugated nozzles and XI-Wobbler emitters, in which the water depth applied in the crop decreased from the center to the end of the area.

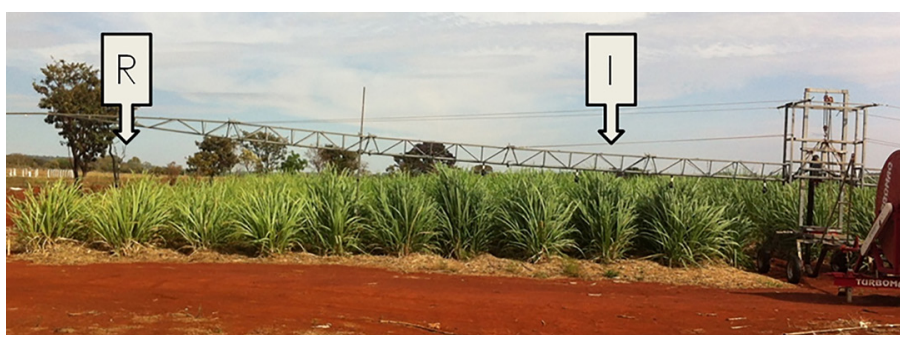

Figure 2. Irrigation bar with self-propelled system and conjugated nozzles, showing the experimental plots: rainfed (R) and irrigated (I). Embrapa Cerrados, Planaltina-DF (2013). 
The experiment was performed in a completely randomized block design with three replications in subdivided plots, with three varieties: RB855156, RB835486 and RB867515 (plot), absence and presence of irrigation (irrigated and rainfed - subplot) and six data collections over time (50, 100, 150, 200, 250 and 300 days after cutting - DAC) that were the subsubplots, except for the productivity data that were used only in the factors: variety (plot) and Irrigation (subplot). Each plot was composed of a row of plants with $4.0 \mathrm{~m}$ long and $1.5 \mathrm{~m}$ wide, with an useful central area of $3.0 \mathrm{~m}$, and $0.5 \mathrm{~m}$ on each side being discarded to avoid the effect of the border.

For the irrigated treatment, the plots were irrigated and received irrigation depth corresponding to $100 \%$ of the crop evapotranspiration (ETC). In the rainfed treatment, water supply was completely suspended after rescue irrigation, in an attempt to reproduce the reality of the production systems of some sugarcane industries in the Midwest region, which has sugarcane plantations implanted in areas under long periods of water deficiency due to seasonality rainfall (Figure 2).

After the fourth harvest, the three sugarcane varieties were evaluated for their biometric responses over the growing period. For each different characteristic analyzed, five plants of each variety were randomly collected in the useful area. The following biometric characteristics were evaluated: mean stem diameter (MSD), mean tiller height (AMP), number of fully open green leaves (NoFOGL), leaf length and leaf width $+3(C+3$ and $L+3$ respectively), leaf area index (LAI), leaf area (LA) and productivity. In the evaluations of leaf dimensions, the leaf was denominated as +3 , according to the Kuijper system (Gírio et al., 2015), because it was completely developed from the physiological point of view and totally unfolded morphologically.

The MTH was measured using a measure tape, measuring from soil level up to the height of the highest leaf projection of the selected tiller.

The NoFOGL was quantified in each of the selected tillers, considering all leaves completely open from leaf +1 (Gírio et al., 2015).
It was considered as green all leaves that had $50 \%$ of the leaf lamina visually green and that were completely expanded (Silva, 2012a).

$L+3$ and $C+3$ data were obtained by measurements in the median portion and in the extreme points of leaves +3 , respectively, with a measure tape.

LAI was determined using the LAI-2000 Plant Canopy Analyzer (Li-cor® Biosciences). The apparatus was configured to perform seven readings, one above the canopy and six below, at the ground level, repeating the procedure for each of the five randomly selected plants.

Leaf area (LA) was calculated by the equation of Hermann and Câmara according to Silva et al (2012a): $A L=C \times L \times 0.75 \times(N+2)$, where: $L A=$ leaf area of the stem (in $\mathrm{cm} 2$ ); $C=$ leaf length $+3(\mathrm{~cm}) ; \mathrm{L}=$ leaf width $+3(\mathrm{~cm}) ; 0.75$ = form factor; $\mathrm{N}=$ number of leaves totally open and with at least $20 \%$ of green area (leaf 0 to leaf +7); 2 = correction factor.

The harvest of the experiment in the fourth cut of sugarcane crop was performed manually, starting on April 4, 2014, at 335 days after cutting (DAC). The stems of the useful plot area were harvested, corresponding to the subplot in the rainfed regime (0\% of the ETC) and the subplot of the irrigated regime (100\% ETC); unpacking the straw, counted and weighed for the determination of productivity, which was expressed in megagrams of stems per hectare $\left(\mathrm{Mg} \mathrm{ha}^{-1}\right)$. A Kern HCB Model 99K50 balance was used to weigh the stems.

The data was submitted to analysis of variance by the $\mathrm{F}$ test at $5 \%$ probability and, when necessary, the polynomial regression analysis was performed for the hydric replacement levels. The means were compared by the Tukey test at $5 \%$ probability.

\section{Results and Discussion}

According to the results of the variance analysis, it was verified that all the biometric characteristics evaluated, with exception of productivity, were significantly different for the varieties (V), as well as for the water regime (WR) on the different days after cutting (DAC). It was observed a significant effect for the complete model (triple interaction) of the factorial 
arrangement with time-subdivided plots for MSD, $\mathrm{C}+3$, NoFOGL and LA (Table 2).

In general, the unfolding effects of triple interactions are complex and the statistical inference is fragile, especially when the repeatability of the experimental results must be verified in the field. However, the understanding of this interaction is crucial for understanding the complex arrangement of factors governing metabolic reactions that result in resistance, tolerance or susceptibility of plant species and contrasting environmental conditions (Rosário et al., 2005). Therefore, it is suggested as responsives the double interaction models in all evaluated variables, except for LAI that was only significant for the isolated effect. So, result returns flexibility choice of the responsive model for biological characterization of the response, being also complemented with the unfolding of the qualitative factors (Table 3).

The RB867515 variety showed a quadratic trend with higher values during the crop cycle to MSD on irrigated regime (Figure 3A) and independent MTH when cultivated by both irrigated and rainfed regimes (Figure 3C, Figure 3D and Table 3). On the other hand, the variety RB835486 obtained the lowest MTH values, both in irrigated and rainfed regimes (Figure $3 \mathrm{C}$ and D); however, it was observed that quickly after the start of the rainy season (137 DAC), the plants cultivated in the rainfed regime, even with values lower than the other varieties tested, increased its growth rate, reaching at 300 DAC with similar height to the variety RB855156 (Figure 3D).

In the MSD, RB867515 reached the maximum value at 228 days of cultivation, reaching $39.51 \mathrm{~mm}$ in treatments under irrigation. However, when cultivated in rainfed regime, there was a decrease of $13 \%$ of this value. The varieties RB835486 and RB855156 reached maximum MSD values at 252 and 243 DAC, with values of 36.36 and $35.02 \mathrm{~mm}$, respectively in the irrigated eratment. For cultivation on the rainfed regime, reductions of $6.94 \%$ and $6.62 \%$ were observed in those cultivars, both with lower MSD reduction than for RB867515 (Figures 3 A and B).

The MSD presented higher results than those observed by Silva et al. (2012a) when they studied the sugarcane ratoon irrigated in the Sub-Midle São Francisco Valley. The authors observed that the growth was more expressive in the first 100 days of the culture cycle and with the MSD of $26.7 \mathrm{~mm}$ at the $132 \mathrm{DAC}$, after which culture presented constant values. For irrigated treatments, the values obtained were higher than those obtained by Costa et al. (2011). The reduction of MSD values and the reduction in growth rate and stabilization of MTH values is an expected response to the phenological phase of stem maturation, which occurs by voting for

Table 2. Resume of the variance analysis of physiological parameters: Mean stem diameter (MSD), mean tiller height (MTH), leaf length $(C+3)$ and leaf width $(L+3)+3$, number of fully open green leaves (NoFOGL), leaf area (LA), leaf area index (LAl) and productivity of the sugarcane varieties RB835486, RB855156 and RB867515, cultivated in irrigated and rainfed systems. Embrapa Cerrados, Planaltina-DF (2013).

\begin{tabular}{|c|c|c|c|c|c|c|c|c|c|c|}
\hline \multirow{2}{*}{ SoV } & \multirow{2}{*}{ DF } & \multicolumn{7}{|c|}{ Mean Square } & \multirow[b]{2}{*}{ DF } & \multirow[b]{2}{*}{ Productivity } \\
\hline & & MSD & MTH & $C+3$ & $L+3$ & NoFOGL & LA & LAl & & \\
\hline Block & 2 & $12.14^{\mathrm{ns}}$ & $0.03^{\text {ns }}$ & $187.69^{\text {ns }}$ & $0.14^{\text {ns }}$ & $0.41^{\text {ns }}$ & $762110.18^{\text {ns }}$ & $0.10^{\text {ns }}$ & 2 & $446.06^{\text {ns }}$ \\
\hline Varieties (V) & 2 & $174.92 *$ & $2.25^{* *}$ & $1123.51^{*}$ & $11.54^{* *}$ & $30.67^{* *}$ & $12831579.15^{* *}$ & $1.65^{*}$ & 2 & $2187.06^{*}$ \\
\hline Residue a & 4 & 11.00 & 0.07 & 115.75 & 0.05 & 1.16 & 537379.83 & 0.12 & 4 & 340.22 \\
\hline$H R$ & 1 & $545,85^{* *}$ & $2.68^{* *}$ & $2438.65^{* *}$ & $8.00^{* *}$ & $47.20^{* *}$ & $37525919.58^{* *}$ & $12.00 * *$ & 1 & $650.71^{\text {ns }}$ \\
\hline$V \times H R$ & 2 & $1.85^{\mathrm{ns}}$ & $0.01^{\mathrm{ns}}$ & $380.65^{\text {ns }}$ & $0.10^{\text {ns }}$ & $5.35^{* *}$ & $1529775.18^{* *}$ & $0.12^{\mathrm{ns}}$ & 2 & $141.72^{\text {ns }}$ \\
\hline Residue b & 6 & 1.80 & 0.04 & 82.84 & 0.05 & 0.41 & 104625.44 & 0.18 & 6 & 544.06 \\
\hline DAC & 5 & $1025.22^{* *}$ & $25.56^{* *}$ & $13722.62^{* *}$ & $30.05^{* *}$ & $88.72^{* *}$ & $134094421.00^{* *}$ & $33.67^{* *}$ & - & - \\
\hline$V \times D A C$ & 10 & $11.29 * *$ & $0.22^{* *}$ & $50.35^{*}$ & $0.34^{* *}$ & $3.01^{* *}$ & $1151617.16^{* *}$ & $0.13^{\text {ns }}$ & - & - \\
\hline$H R \times D A C$ & 5 & $33.28^{* *}$ & $0.25^{* *}$ & $304.17^{* *}$ & $0.48^{* *}$ & $5.71^{* *}$ & $2447410.25^{* *}$ & $0.09^{\text {ns }}$ & - & - \\
\hline$V \times H R \times D A C$ & 10 & $2.28^{\text {ns }}$ & $0.09 *$ & $96.13^{* *}$ & $0.06^{\mathrm{ns}}$ & $0.64^{* *}$ & $477582.98^{* *}$ & $0.16^{\text {ns }}$ & - & - \\
\hline Residue c & 60 & 1.58 & 0.04 & 21.83 & 0.06 & 0.21 & 128781.08 & 0.09 & - & - \\
\hline mean & & 28.60 & 2.50 & 144.28 & 4.27 & 5.62 & 4449.34 & 3.36 & & 154.28 \\
\hline VCl (\%) & & 11.60 & 10.18 & 7.46 & 5.48 & 19.17 & 16.48 & 10.23 & & 11.96 \\
\hline VC2 (\%) & & 4.69 & 7.58 & 6.31 & 5.35 & 11.44 & 7.27 & 12.54 & - & 15.12 \\
\hline VC3 (\%) & & 4.39 & 7.68 & 3.24 & 5.81 & 8.08 & 8.07 & 8.96 & - & - \\
\hline
\end{tabular}


Table 3. Mean tiller height (MTH), length $(C+3)$, number of fully open green leaves (NFOGL), leaf area (LAC) and productivity of sugarcane varieties RB835486, RB855156 and RB867515, grown in irrigated and rainfed systems. Embrapa Cerrados, Planaltina-DF (2013).

\begin{tabular}{|c|c|c|c|c|c|c|}
\hline \multirow[b]{3}{*}{ Variety } & \multicolumn{6}{|c|}{ Days after cutting } \\
\hline & \multicolumn{2}{|c|}{50} & \multicolumn{2}{|c|}{100} & \multicolumn{2}{|c|}{150} \\
\hline & I & $R$ & I & $R$ & I & $R$ \\
\hline RB835486 & $1.00^{\mathrm{aA}}$ & $1.00^{\mathrm{aA}}$ & $1.87^{\mathrm{aA}}$ & $1.26^{\mathrm{bB}}$ & $2.00^{\mathrm{bA}}$ & $1.53^{\mathrm{bB}}$ \\
\hline RB855156 & $1.00^{\alpha \mathrm{A}}$ & $1.00^{\mathrm{aA}}$ & $1.87^{\mathrm{aA}}$ & $1.73^{\mathrm{aA}}$ & $2.01^{\mathrm{bA}}$ & $1.93^{\mathrm{aA}}$ \\
\hline RB867515 & $1.00^{\alpha \mathrm{A}}$ & $1.00^{a A}$ & $2.00^{\mathrm{aA}}$ & $1.80^{\mathrm{aA}}$ & $2.47^{a A}$ & $1.93^{\mathrm{aB}}$ \\
\hline RB835486 & $100.07^{\mathrm{bA}}$ & $94.73^{\mathrm{aA}}$ & $117.40^{\mathrm{bA}}$ & $111.13^{\mathrm{aA}}$ & $149.53^{\mathrm{bA}}$ & $132.20^{\mathrm{bB}}$ \\
\hline RB855156 & $113.93^{a B}$ & $95.93^{\mathrm{aA}}$ & $133.80^{\mathrm{aA}}$ & $112.73^{a B}$ & $165.87^{a A}$ & $125.00^{\mathrm{bB}}$ \\
\hline RB867515 & $107.07^{\mathrm{aba}}$ & $101.73^{a A}$ & $125.87^{\mathrm{abA}}$ & $119.60^{\mathrm{aA}}$ & $153.47^{\mathrm{bA}}$ & $146.40^{\mathrm{aA}}$ \\
\hline RB835486 & $2.40^{\mathrm{bA}}$ & $2.00^{\mathrm{aA}}$ & $3.13^{\mathrm{bA}}$ & $2.13^{a b}$ & $5.07^{\mathrm{bA}}$ & $2.20^{\mathrm{bB}}$ \\
\hline RB855156 & $4.40^{\mathrm{aA}}$ & $2.13^{\mathrm{aB}}$ & $5.40^{\mathrm{aA}}$ & $2.73^{a B}$ & $7.47^{\mathrm{aA}}$ & $3.60^{\mathrm{aB}}$ \\
\hline RB867515 & $3.93^{\mathrm{aA}}$ & $2.07^{a B}$ & $4.93^{\mathrm{aA}}$ & $2.60^{\mathrm{aB}}$ & $6.87^{\mathrm{aA}}$ & $4.33^{\mathrm{aB}}$ \\
\hline RB835486 & $1280.67^{\mathrm{bA}}$ & $911.67^{\mathrm{aA}}$ & $2007.33^{\mathrm{bA}}$ & $\begin{array}{c}c\left(\mathrm{~cm}^{2}\right) \\
1299.67^{\mathrm{aB}}\end{array}$ & $4045.60^{\mathrm{bA}}$ & $1726.07^{\mathrm{bB}}$ \\
\hline RB855156 & $1328.33^{\mathrm{abA}}$ & $719.80^{\mathrm{aB}}$ & $2086.67^{\mathrm{bA}}$ & $1118.67^{a B}$ & $4397.67^{\mathrm{bA}}$ & $1558.93^{\mathrm{bB}}$ \\
\hline \multirow[t]{3}{*}{ RB867515 } & $1999.27^{\mathrm{aA}}$ & $1155.07^{a в}$ & $3167.00^{\mathrm{aA}}$ & $1772.93^{a B}$ & $5296.80^{a A}$ & $3070.27^{a B}$ \\
\hline & \multicolumn{6}{|c|}{ Days after cutting } \\
\hline & \multicolumn{2}{|c|}{200} & \multicolumn{2}{|c|}{250} & \multicolumn{2}{|c|}{300} \\
\hline Variety & I & $R$ & I & $R$ & I & $R$ \\
\hline RB835486 & $2.60^{\mathrm{bA}}$ & $1.80^{\mathrm{bB}}$ & $3.00^{\mathrm{bA}}$ & $3.00^{\mathrm{bA}}$ & $4.07^{\mathrm{bA}}$ & $4.00^{\mathrm{bA}}$ \\
\hline RB855156 & $3.00^{\mathrm{aA}}$ & $2.33^{a B}$ & $3.87^{\mathrm{aA}}$ & $3.13^{\mathrm{bB}}$ & $4.00^{\mathrm{bA}}$ & $4.00^{\mathrm{bA}}$ \\
\hline RB867515 & $3.13^{a A}$ & $2.60^{\mathrm{aB}}$ & $4.00^{\mathrm{aA}}$ & $3.53^{a в}$ & $4.93^{\mathrm{aA}}$ & $4.67^{\mathrm{aA}}$ \\
\hline RB835486 & $166.00^{\mathrm{aA}}$ & $148.27^{\mathrm{bB}}$ & $153.87^{\mathrm{CA}}$ & $161.13^{\mathrm{bA}}$ & $163.00^{\mathrm{bA}}$ & $161.00^{\mathrm{bA}}$ \\
\hline RB855156 & $169.27^{\mathrm{aA}}$ & $150.47^{\mathrm{bB}}$ & $171.07^{\mathrm{bA}}$ & $166.47^{\mathrm{abA}}$ & $169.53^{\mathrm{abA}}$ & $171.47^{a A}$ \\
\hline RB867515 & $166.47^{\mathrm{aA}}$ & $162.33^{\mathrm{aA}}$ & $182.40^{a A}$ & $173.27^{a B}$ & $173.93^{\mathrm{aA}}$ & $177.60^{\mathrm{aA}}$ \\
\hline RB835486 & $6.27^{\mathrm{CA}}$ & $6.93^{\mathrm{aA}}$ & $6.07^{\mathrm{cA}}$ & $6.60^{\mathrm{cA}}$ & $6.87^{\mathrm{bA}}$ & $6.13^{\mathrm{bA}}$ \\
\hline RB855156 & $8.33^{a A}$ & $7.07^{a B}$ & $10.93^{a A}$ & $10.47^{\mathrm{aA}}$ & $8.87^{\mathrm{aA}}$ & $6.47^{a b B}$ \\
\hline RB867515 & $7.33^{\mathrm{bA}}$ & $6.40^{\mathrm{aB}}$ & $8.20^{\mathrm{bA}}$ & $8.27^{\mathrm{bA}}$ & $6.53^{\mathrm{bA}}$ & $7.07^{\mathrm{aA}}$ \\
\hline RB835486 & $5516.53^{\mathrm{bA}}$ & $4389.80^{\mathrm{abB}}$ & $5778.47^{\mathrm{bA}}$ & $\begin{array}{c}\left(\mathrm{cm}^{2}\right) \\
6240.13^{\mathrm{bA}}\end{array}$ & $7051.73^{\mathrm{bA}}$ & $6555.40^{\mathrm{bA}}$ \\
\hline RB855156 & $6168.07^{\mathrm{abA}}$ & $4063.27^{\mathrm{bB}}$ & $8476.60^{\mathrm{aA}}$ & $7032.53^{а в}$ & $8471.20^{\mathrm{aA}}$ & $6932.80^{\mathrm{bB}}$ \\
\hline RB867515 & $6471.27^{\mathrm{aA}}$ & $4836.53^{a B}$ & $8416.73^{\mathrm{aA}}$ & $7004.13^{a B}$ & $8738.47^{\mathrm{aA}}$ & $9090.07^{a A}$ \\
\hline
\end{tabular}

the 300 days of crop cycle, being a response to the phenological maturation phase of the stem, when the plant maintains the metabolic activities, according to Oliveira et al. (2007).

For MTH, when cultivated in rainfed conditions there was a reduction in growth rate at the beginning of the cycle, recovering with the resumption of rainfall in the region that occurred at the 137 DAC, however, the variety RB835486 had a greater initial reduction in height mean of the tiller. The rainy season favored the recovery of MTH throughout the crop cycle, but the variety RB867515 presented higher results than the other varieties studied (Table 3), showing that this variety had a satisfactory recovery with the rainfall occurred in Cerrado. The MTH values obtained in the present study were higher than those reported by Machado et al. (2009) studying biometric and physiological responses to hydric deficit in different phenological phases of sugarcane varieties. These results reinforce the study of these biometric characteristics as indicative of tolerance to hydric stress for sugarcane as proposed by Silva et al. (2012a).

The growth limitation is considered as the first defense mechanism of the crop to hydric deficit. The events that depend on the cellular turgidity stay uncertain, being the first 


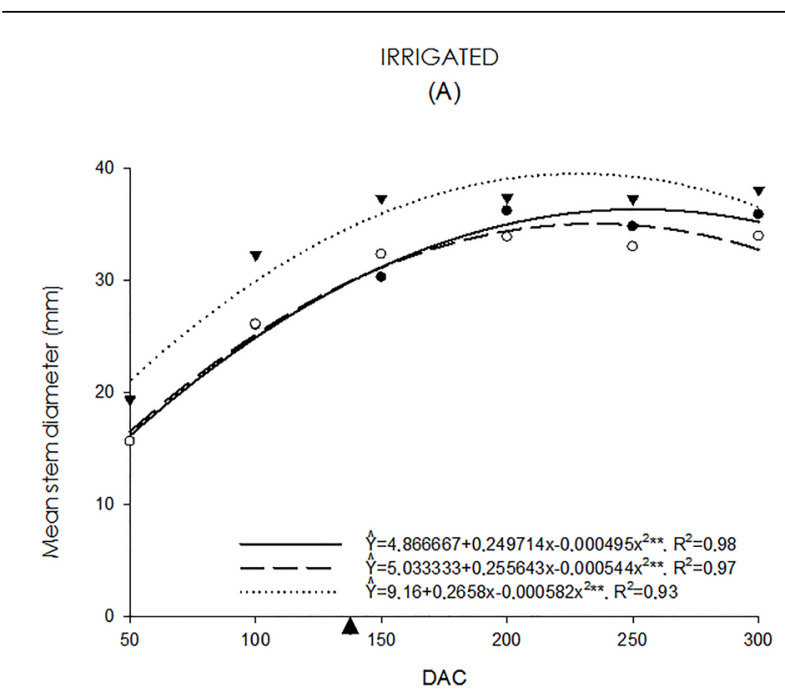

(C)

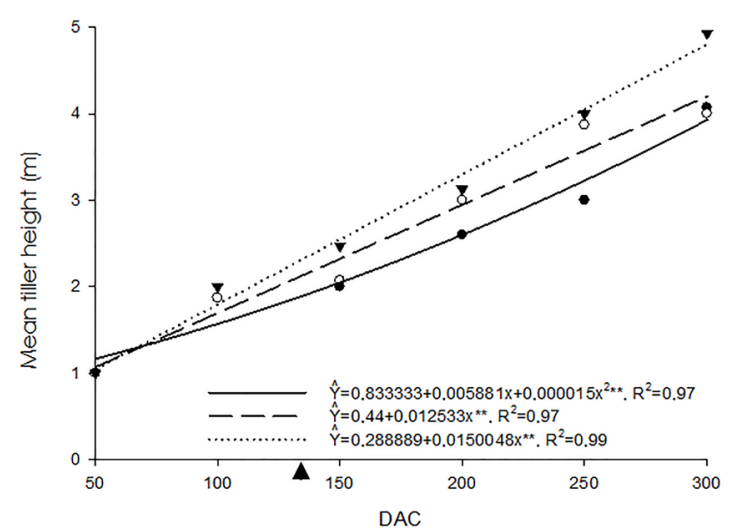

RAINFED

(B)

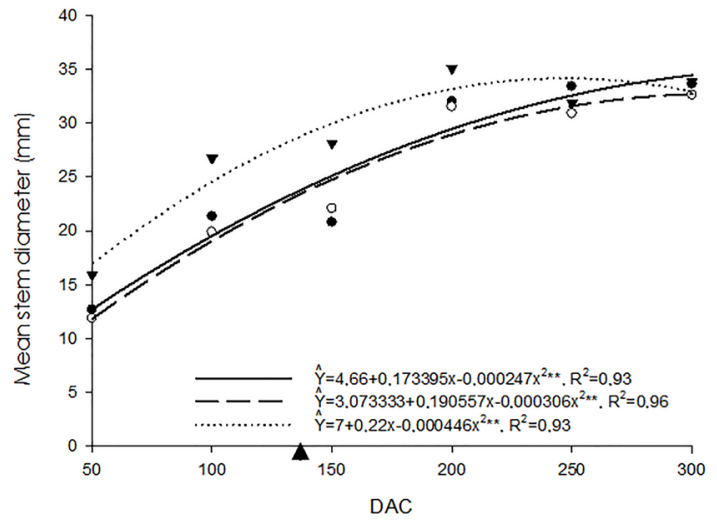

(D)

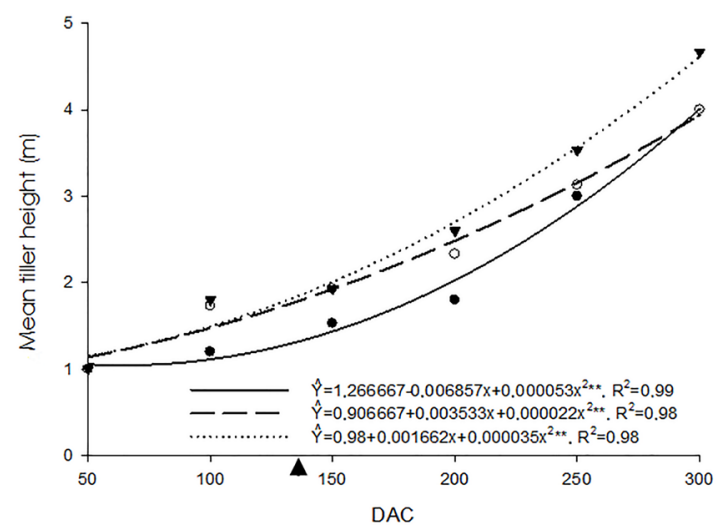

DAC

Figura 3.Mean stem diameter (MSD) and Mean tiller height (MTH) of varieties RB835486 (__ •), RB855156 (----- o) and RB867515 (...... V) sugarcane, cultivated in irrigated and rainfed systems, according to the days after cutting (DAC). Embrapa Cerrados, Planaltina-DF (2013). ( $\square$ ) - beginning of the rainy season.

ones to express response to the lower availability of water in the plant, by reducing leaf area and root growth (Taiz \& Zeiger, 2013). Thus, a decrease in the transpiration surface area occurs, maintaining a minimum water supply in the soil for a longer period (Taiz \& Zeiger, 2013). According to Inman-Bamber \& Smith (2005), plant growth is directly affected in situations of water restriction, since the elongation and cell division are reduced, causing a decrease in leaf expansion and stem growth, which may also influence the quality of the product by reducing soluble solids accumulation in the stem. Koehler (1982) explains that a plant under conditions of water stress can have its growth reduced in up to $80 \%$.

The length of leaf +3 showed that the irrigated plants reached the maximum value $163.15,137.54$ and $163.15 \mathrm{~cm}$ at $255.74,243.97$ and 290.32 DAP for the varieties RB835486,
RB855156 and RB867515, respectively (Figure $4 \mathrm{~A})$. For these varieties under rainfed conditions was observed a slower development compared to the irrigated conditions, and these varieties reached 161.00; 171.47 and $177.60 \mathrm{~cm}$ at 300 DAC (Table 3). These results are superior to $146 \pm$ $6 \mathrm{~cm}$ (maximum at $238 \mathrm{DAC}$ ) observed by Silva et al. (2012a) studying the biometry of sugarcane of the variety RB92579, cultivated under irrigation in the Sub-Middle São Francisco Valley. The variety RB867515 presented the highest values for the length and width of the leaf +3 , both for the irrigated and rainfed treatments, which confirms its good adaptation to the water restriction. It was also possible to notice that during the period of water stress, in relation to the irrigated treatments, there was a reduction of leaf width +3 and its recovery with the beginning of the rainy season (Figures $4 \mathrm{C}$ and $\mathrm{D}$ ).

Under irrigation, the varieties RB835486, 


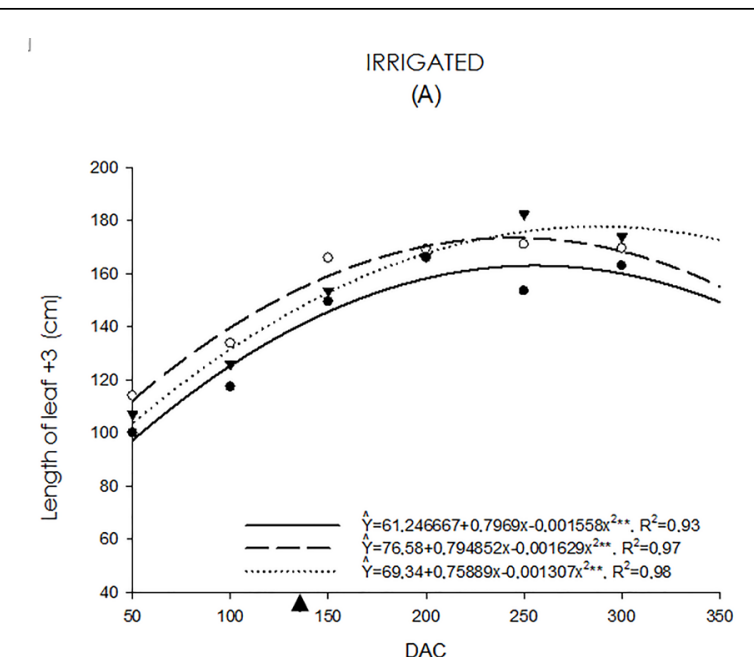

(C)

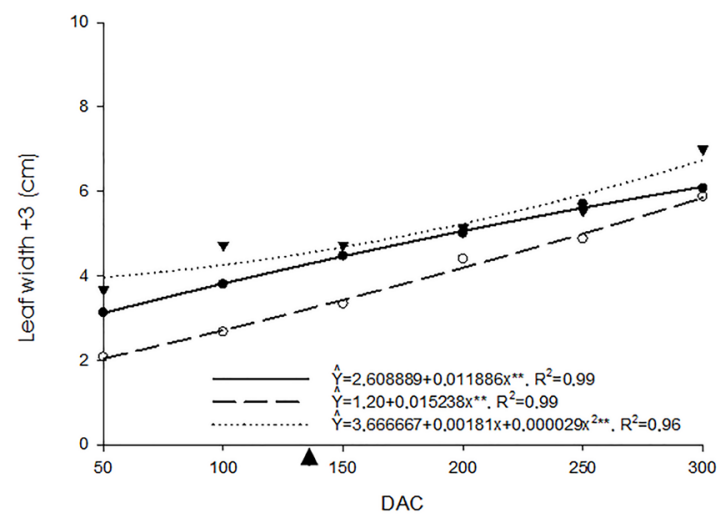

RAINFED

(B)

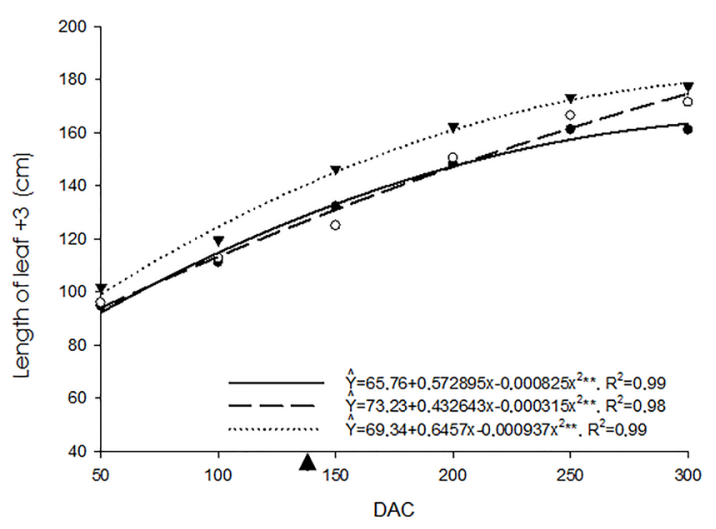

(D)

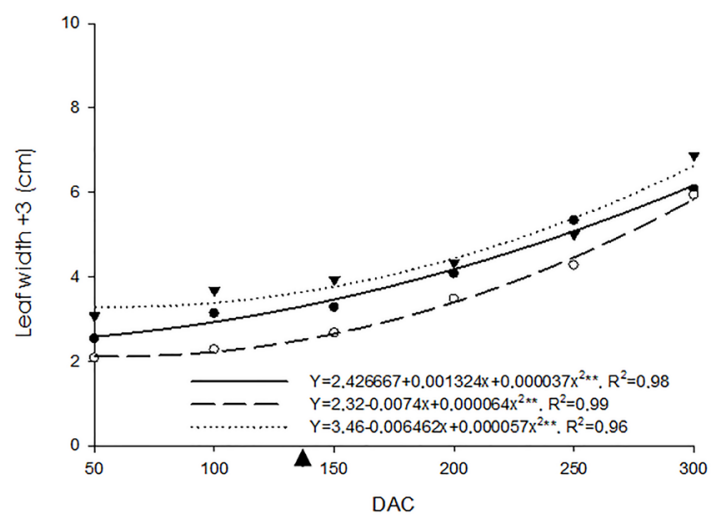

Figure 4. Length of leaf $+3(C+3)$, leaf width $+3(L+3)$ of tillers of RB835486 (__ • • RB855156 (---- o) and RB867515 (...... $)$ ) of sugarcane varieties, cultivated in irrigated and rainfed systems, as a function of days after cutting (DAC). Embrapa Cerrados, Planaltina-DF (2013). ( $\mathbf{\nabla}$ ) - beginning of the rainy season.

RB867515 and RB855156 showed a quadratic behavior during the growing cycle and reached a maximum of $6.75,7.55$ and 9.65 NoFOGL at $300,227.36$ and 296.51 DAC, respectively. For the cultivate on rainfed, it was observed that the release of green leaves was slower in this

IRRIGATED

(A)

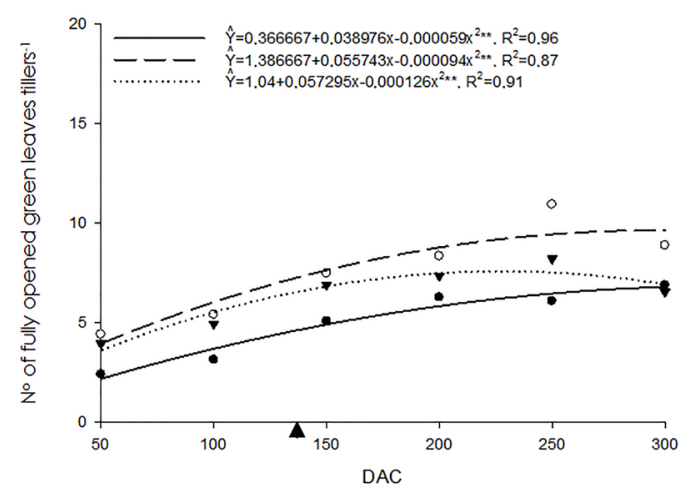

cultivation, reaching 300 DAC with 6.82, 7.79 and 8.09 NoFOGL (Figures $5 \mathrm{~A}$ and B). With the exception of the variety RB855156, the reduction of the green leaves in the cultivation on rainfed regime caused a greater intensity in the varieties RB835486 and RB867515.
RAINFED

(B)

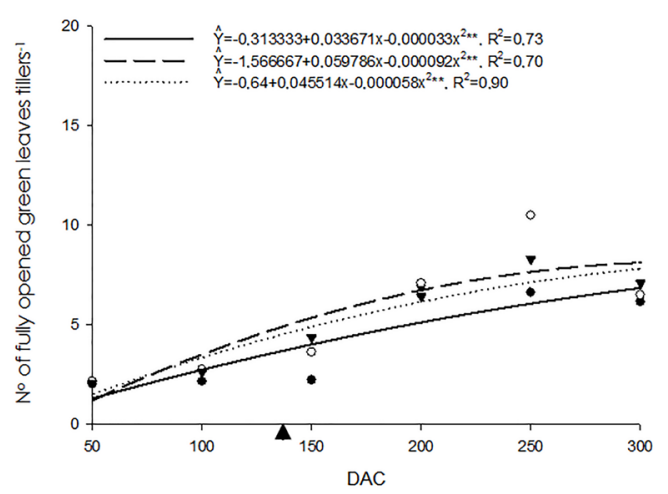

Figure 5. Number of fully opened green leaves (NoFOGL) for tillers of the cultivated varieties RB835486 (__ • RB855156 (--- ) and RB867515 (...... $\mathbf{\nabla})$ in irrigated and rainfed systems, according to the days after cutting (DAC). Embrapa Cerrados, Planaltina-DF (2013). ( $\square$ ) - beginning of the rainy season. 
Similar results were obtained by Oliveira et al. (2007) for the RB72454, RB855113 and RB855536 varieties, verifying maximum values for the NoFOGL between 8 and 9, although there were fewer leaves up to 231 DAP; a period that corresponds to the end of the phase of greater tillering of sugarcane. From this time on, authors affirm that that there was an increase on the number of green leaves, culminating at 377 DAPS, for the RB72454 and RB855113 varieties, and at 428 DAP for the variety RB855536. The results for NoFOGL also corroborate with those reported by Machado et al. (2009), which verified that under water stress there was a reduction in the number of green leaves, although they did not observe differences between different varieties tested (IACSP 94-2094 and IACSP 96-2042). According to Smit \& Singels (2006) this behavior is dependent on the genetic potential of each variety. However, Silva et al. (2012a) registered values of 6 to 8 for the NoFOGL when evaluating the sugarcane RB92579 variety in irrigated cultivation in the SubMiddle São Francisco Valley, noticing also that observed minor values in the finish of the cycle due to the decrease of the new leaves emission by plants and the increased senescence rate, reaching the highest NoFOGL value (8 leaves stem $^{-1}$ ) between 200 and 250 DAC.

The reduction in NoFOCOGL is probably due to the end of the phase of intense growth (279 to 377 DAP), when sugarcane decreases energy consumption for the production of green leaves. This reduction in the number of green leaves is also reported when plants are cultivated with hydric deficit, and it is attributed to the strategy for reducing the transpiration surface, reducing metabolic spend for tissue maintenance (Inman-Bamber \& Smith, 2005; Smit \& Singels, 2006; Inman-Bamber et al., 2008). The consequent reduction in the amount of plant leaves caused by the cessation of leaf emergence are responses to the hydric deficit, which can occur in many ways according to each genotype (Smit \& Singels, 2006), and at the same time, the NoFOGL is one probable indicator of the effect of hydric deficit on sugarcane, as suggested by Inman-Bamber \& Smith (2005). This reduction of NOFOGL in rainfed cultivation reinforces the justification that sugarcane plants when submitted to a hydric deficit situation that, in addition to accelerating senescence of the older leaves, which may be related to the increase in the synthesis of abscisic acid (Taiz \& Zeiger, 2013), they may reduce the number of emergent leaves, which can vary according to the genetic potential of each variety. The decrease in the opening and growth of the leaves is affected by the minor water absorption, which causes the plant to accumulate young leaves no expand for a longer time, thus reducing the leaf surface and consequently the water demand. However, the plant returns to the normal growth rate when the water supply is normalized (Inman-Bamber \& Smith, 2005), as observed for varieties BR835486 and BR867515 in Table 3 at 300 DAC.

The variety RB867515 also presented the highest value for LA and LAI under rainy conditions. However, even with lower values, the variety RB855156 responded in a similar way to the same variable (Figure 6 and Figure 7). In the isolated effect for the LAl, the RB835486 variety presented lower LAI compared to the other tested varieties (Figure 7 and Table 3). Under irrigation, the genotypes presented a leaf area increase, obtaining 9001.60, 8973.59 and 7001.85 $\mathrm{cm}^{2}$ at 300 DAC for the varieties RB867515, RB855156 and RB835486, respectively. For rainfed cultivation, a fast recovery was observed in the LA, reaching at 300 DAC values: $9213.39,7689.82$ and $7102.36 \mathrm{~cm}^{2}$. The RB855156 was the variety that showed the minor recover with rainy season return, causing loss of $14 \%$ in its leaf area in the rainfed condition (Figures $6 \mathrm{~A}$ and $\mathrm{B}$ ). The other varieties (RB835486 and RB867515) recovered the $L A$, reaching the end of the cycle with similar values to irrigation treatments.

The varieties cultivated under irrigation RB867515, RB855156 and RB835486 at 300 DAC showed LAI of 5.73, 5.60 and 5.40, respectively, with a reduction of $11.69,9.46$ and $5.0 \%$ when grown in rainfed conditions. It was observed that the variety RB835486, even with a reduction of only $5.0 \%$ when cultivated under water restriction, continued with the lowest value of LAI. It was verified that at the beginning of the water stress during the crop cycle, there was a reduction in the NoFOGL and the size of the tiller leaves for all varieties (Figures 4 and 5), promoting a reduction 

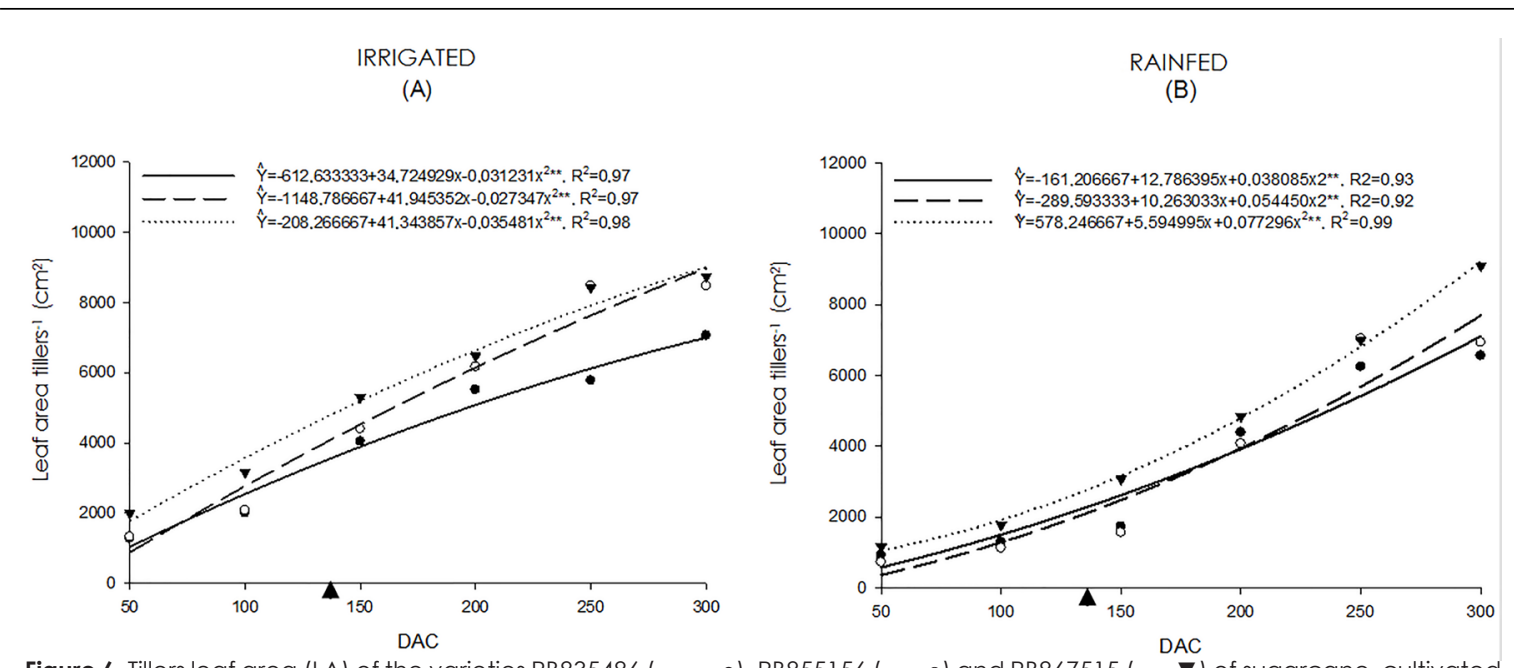

Figure 6. Tillers leaf area (LA) of the varieties RB835486 (___ • ), RB855156 (---- o) and RB867515 (.......V) of sugarcane, cultivated in an irrigated and rainfed systems, according to the days after cutting (DAC). Embrapa Cerrados, Planaltina-DF (2013). ( $\square$ ) beginning of the rainy season.

(A)

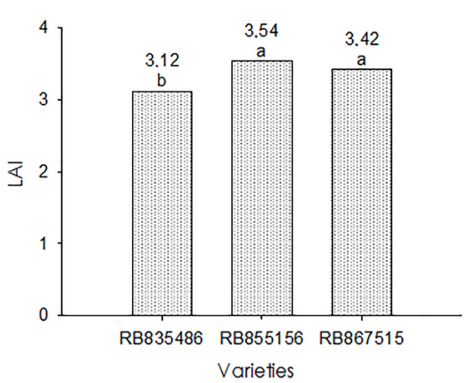

(B)

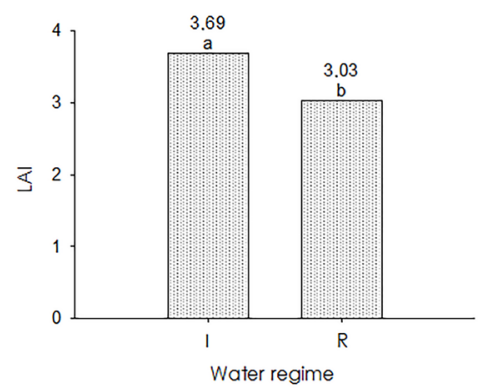

(C)

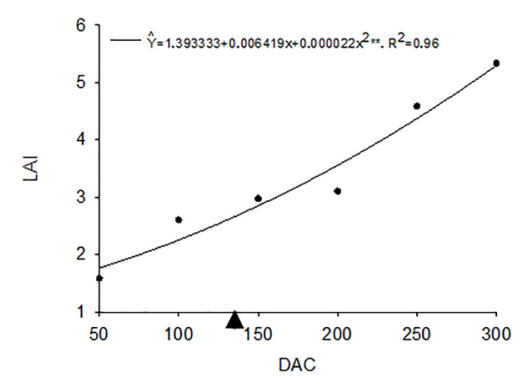

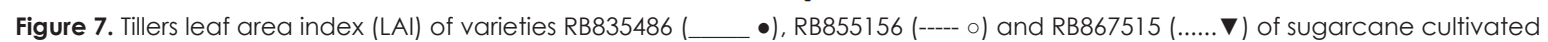
in an irrigated and rainfed systems. Embrapa Cerrados, Planaltina-DF (2013). ( $\square$ ) - beginning of the rainy season.

of the LA and LAI (area to sunlight absortion), respectively. In addition, there is a reduction in water demand for the crop and a decrease in water loss due to transpiration and metabolic activities of tissue maintenance (Inman-Bamber \& Smith, 2005; Smit \& Singels, 2006; Inmam-Bamber et al., 2008, Machado et al., 2009). However, as mentioned before, sugarcane plants return to their normal development, as soon as the water supply normalizes to that demanded by the crop (Inman-Bamber \& Smith, 2005). This is one of the reasons for use this biometric feature as one of the main indicators of the water stress effects on sugarcane crops (Inmam-Bamber, 2004).

The LAl values were higher than those observed by Costa et al. (2011), studying growth and productivity of four sugarcane varieties in the fourth crop cycle, when they observed that in the harvest period, the variety RB93509 reached a maximum of 4.2 , followed by SP791011 with 3.4, RB92579 with 2.7 and RB931530 with 2.5. Similar results to LAI were reported by Silva et al. (2012a) testing sugarcane varieties in rainfed and irrigated systems: the authors also reported the good performance of RB867515, that showed apparently reduced $L A I$ at the beginning of the cycle and recovery near the cutting point. According to Pereira and Machado (1986), the observed LAI with satisfactory values close to 4.0, are able to intercept $95 \%$ of the incident radiation. For RB835486, Shigaki et al. (2004) observed that this variety obtained inferior values in the growth parameters when compared to other varieties of sugarcane cultivated under water stress. Likewise, Silva et al. (2012a) and Ecco et al. (2014) observed that for all the biometric variables tested on the rainfed treatments, result trends were similar, with biometric values decreasing at the beginning of the crop vegetative development when it was cultivated under hydric deficit. However, these authors affirmed that tillers restarted its growth at the beginning of the rainy season together with the elevation of temperatures, which occurred around 137 DAC (Figure 1), usually recovering until the end of the cycle, similar to that occurred in the present research. 
In general, RB867515 was the variety that obtained the highest values of the evaluated biometric data among the tested varieties, and presented higher productivity, with $131.43 \%$ higher than the national average of $73.6 \mathrm{Mg}$ $\mathrm{ha}^{-1}$ (Conab (2014), with no difference between the water regimes used during the cultivation (rainfed or irrigated), but not statistically different from the variety RB855156 (Figure 8).

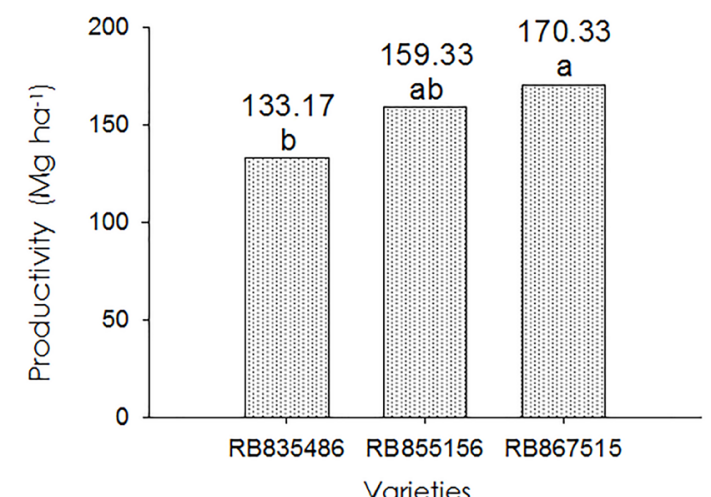

Figure 8. Productivity of the sugarcane varieties RB835486, RB855156 and RB867515 cultivated under variable water regimes. Embrapa Cerrados, Planaltina-DF (2013).

Although there was a reduction in biometric variables for the tested varieties, they showed a satisfactory productivity for the fourth crop cycle, when there is a natural tendency to decline the genotypes potential production (Costa et al., 2011). Even with the natural decline of the cycle, the evaluated varieties, with the exception of RB835486, showed a good adaptability to the climatic conditions of the Midwest Region of Brazil, as well as the region potential for sugar-alcohol sector in Brazil.

Biometric data are used in the selection of genotypes on the process of genetic improvement, also supply databasesformodeling, which allows estimations of crop productivity such as sugarcane (Carlin, 2008). These changes are genetic expressions of the tolerance and may vary according to the response of the sugarcane variety that is chosen for planting (lanmanBamber \& Smith, 2005; Taiz \& Zeiger, 2013), helping in the process of characterization and plant breeding of cultivated varieties Pugnayre et al., 2007; Oliveira et al., 2007), their productive capacity or data collection for growth modeling of the crop in response to different environments and production systems in regions where rainfall is seasonal and with lower availability of water for irrigation use (Inman-Bamber \& Smith, 2005; Oliveira et al., 2007).

\section{Conclusions}

The variety RB867515 showed the highest biometric values to mean stem diameter, mean tiller height, leaf length and leaf width +3 , in both irrigated and rainfed crops.

There was a reduction in the numbers of fully open green leaves (NoFOGL), and increase in number of emergent leaves (NOEL) and number of dead leaves (NoDL) by tiller when the varieties were cultivated in rainfed conditions.

The variety RB867515 showed the highest productivity, not statistically different from RB855156.

There was no significant difference in productivity for the different hydric regimes (rainfed and irrigated).

\section{References}

Camargo, M.S., Vitti, A.C. 2014. Produção de palhada e colmos de variedades de cana-deaçúcar. Pesquisa \& Tecnologia 11: 1-5.

Carlin, S.D., Silva, M.A., Rossetto, R. 2008. Parâmetros biométricos e produtividade da cana-de-açúcar após tombamento dos colmos. Bragantia 67: 845-853.

Carvalho, C.M., Azevedo, H.M., Dantas Neto, J., Farias, C.H.A., Silva, C.T.S., Gomes Filho, R.R. 2009. Rendimento de açúcar e álcool da canade-açúcar submetida a diferentes níveis de irrigação. Revista Brasileira de Ciências Agrárias4: 72-77.

Conab-Companhia Nacional de Abastecimento. 2014. Acompanhamento de safra brasileira: cana-de-açúcar, v.1-Safra 2014/2015, n.1Primeiro levantamento, abril/2014.Conab, Brasília, Brazil, 20 p.

Costa, C.T.S., Ferreira, V.M., Endres, L., Ferreira, D.T.R.G., Gonçalves, E.R. 2011. Crescimento e produtividade de quatro variedades de canade-açúcar no quarto ciclo de cultivo. Revista Caatinga 24: 56-63.

Dantas Neto, J., Figueirêdo, J.L.C., Farias, C.H.A., Azevedo, H.M., Azevedo, C.A.V. 2006. Resposta da cana-de-açúcar, primeira soca, a níveis de irrigação e adubação de cobertura. Revista Brasileira de Engenharia Agrícola e Ambiental10: 283-288.

Ecco, M., Santiago, E.F., Lima, P.R. 2014. Respostas biométricas em plantas jovens de cana-deaçúcar submetidas ao estresse hídrico e ao 
alumínio. Comunicata Scientiae5: 59-67.

EMBRAPA. Centro Nacional de Pesquisa de Solos. 1997. Manual de métodos de análise de solo. 2.ed. Rio de Janeiro, 212p. (Embrapa-CNPS. Documentos, 1).

Farias, C.H.A., Fernandes, P.D., Gheyi, H.R., Dantas Neto, J. 2009. Qualidade industrial de cana-de-açúcar sob irrigação e adubação com zinco, em Tabuleiro Costeiro paraibano. Revista Brasileira de Engenharia Agrícola e Ambiental13: 419-428.

Fernandes, D.S., Heinemann, A.B., Pazii, R.L.F., Amorim, A.O. 2012. Calibração regional e local da equação de Hargreaves para estimativa da evapotranspiração de referência. Revista Ciência Agronômica43:246-255.

Gírio, L.A.S., Dias, F.L.F., Reis, V.M., Urquiaga, S.,Schultz, N., Bolonhezi, D., Mutton, M.A. 2015. Bactérias promotoras de crescimento e adubação nitrogenada no crescimento inicial de cana-de-açúcar proveniente de mudas pré-brotadas. Pesquisa Agropecuária Brasileira50: 33-43.

Inman-Bamber, N.G., Bonnett, G.D., Spillman, M.F., Hewitt, M. L.,Jackson, J. 2008. Increasing sucrose accumulation in sugarcane by manipulating leaf extension and photosynthesis with irrigation. Australian Journal of Agricultural Research59: 13-26.

Inman-Bamber, N.G., Smith, D.M. 2005. Water relations in sugarcane and response to water deficits. Field Crops Research92:185-202.

Machado, R.S., Ribeiro, R.V., Marchiori, P.E.R., Machado, D.F.S.P., Machado, E.C., Landell, M.G.A. 2009. Respostas biométricas e fisiológicas ao deficit hídrico em cana-de-açúcar em diferentes fases fenológicas. Pesquisa Agropecuária Brasileira44: 1575-1582.

Oliveira, R.A., Daros, E., Zambon, J.L.C., Weber, H.,Ido, O.T., Bespalhok-Filho, J.C., Zuffellato-Ribas, K.C., Silva, D.K.T. 2007. Área foliar em três cultivares de cana-de-açúcar e sua correlação com a produção de biomassa. Pesquisa Agropecuária Tropical37: 71-76.

Peixoto, P.H.O., Pimenta, D.L., Cambraia, J. 2007. Alterações morfológicas e acúmulo de compostos fenólicos em plantas de sorgo sob estresse de alumínio. Bragantia66: 17-25.

Pereira, A.R., Machado, E.C. 1986. A dynamic simulator of sugarcane crop growth. Bragantia45: 107-122.

Rosário, M.F., Silva, M.A.N., Savino, V.J.M., Coelho, A.A.D., Moraes, M.C. 2005. Evaluation of the Zootechnical Performance of Broiler Genotypes
Using the Repeated Measurement Analysis. Revista Brasileira de Zootecnia 34: 2253-2261.

Sano. S.M., Almeida, S.P., Ribeiro, J.F. 2008. Cerrado: ecologia e flora. Embrapa: †ecnologic informations, Brasília, Brazil. 1279 p.

Shigaki, F., Freitas, N.,Berto, A., Ceddia, M.B., Zonta, E.,Lima, E. 2004. Influence of water stress on growth parameters, accumulation of $\mathrm{N}$ and productivity of different sugarcane varieties in Miracema - RJ. Revista Universitária Rural-Série Ciências da Vida 24: 63-71.

Silva, M.A., Silva, J.A.G., Enciso, J., Sharma, V., Jifon, J. 2008. Yield components as indicators of drought tolerance of sugarcane. Scientia Agricola65: 620-627.

Silva, T.G.F., Moura, M.S.B., Zolnier, S., Carmo, J.F.A., Souza,L.S.B. 2012a. Biometry of the aerial part of the soca irrigated cane in the Submedia of the São Francisco Valley. Revista Ciência Agronômica43: 500-509.

Silva, T.G.F., Moura, M.S.B., Zolnier, S., Soares, J.M., Vieira, V.J.S., Júnior, W.G.F. 2012b. Water requirement and crop coefficient of irrigated sugar cane in the Brazilian semi-arid region. Revista Brasileira de Engenharia Agrícola e Ambiental 6: 64-71.

Smit, M.A., Singels, A. 2006. The response of sugarcane canopy development to water stress. Field Crops Research98: 91-97.

Taiz, L., Zeiger, E. 2013. Fisiologia vegetal. 5 ed. Artmed, Porto Alegre, Brazil. 918p. 